\title{
One-step preparation of bilayered films from kraft lignin and cellulose acetate to mimic tree bark
}

\author{
Stéphan Barbe ${ }^{1}(1) \cdot$ Moriz Berger $^{1} \cdot$ Roxanne Engstler $^{1} \cdot$ Andrés Dieste $^{2} \cdot$ Leonardo Clavijo $^{2} \cdot$ Evangelos Favvas $^{3}$. \\ Andreas Sapalidis ${ }^{3}$
}

Received: 24 February 2020 / Published online: 27 May 2020

(c) The Author(s) 2020

\begin{abstract}
This contribution presents the development of a dry-cast method for the one-step preparation of bio-based films from wood polymers that mimic the bilayered structure of tree bark, the natural protective layer of the tree. In a simplified view, natural bark can be considered as the superposition of an external homogeneous and non-porous layer (outer bark) and a porous substructure layer (inner bark). This work is a first step for the future development of bio-based biomimetic wood coatings. The film had a bark-like appearance and its total density, bulk density and porosity were similar to values measured in natural bark. Furthermore, the structural characteristics of the studied film, namely specific surface area (BET) and pore size distribution, as well as the performance of the water adsorption ability were investigated and discussed.
\end{abstract}

\section{Introduction}

In living trees, wood is protected by bark, a non-technical term to describe a complex multilayered tissue, formed by dead and living portions (Crang et al. 2018). Tree bark is a natural barrier between the environment and the wood, which protects the tree from the sun (scorching), the wind (drying), weathering, fire damage, mechanical impact, and biological attacks (fungi and insects).

Based on the method described by Musa et al. (2018) for the dry-cast preparation of macroporous films from cellulose acetate (CA) and acetylated lignin (LA), the objective of this work was to prepare bilayered films (BF) from CA and kraft lignin $(\mathrm{KL})$ that mimic the structure of tree bark, which-in a simplified view_can be regarded as the superposition of outer bark as a solid non-porous film and inner bark as a porous sublayer. LA is not yet commercially available and its large-scale production is quite challenging. For this reason, it was decided to modify the method by substituting LA by

Stéphan Barbe

stephan.barbe@th-koeln.de

1 Faculty of Applied Natural Sciences, Technische Hochschule Köln, Leverkusen, Germany

2 Faculty of Engineering, Universidad de la República, Montevideo, Uruguay

3 Institute of Nanoscience and Nanotechnology, NCSR "Demokritos", Attica, Greece
$\mathrm{KL}$, which is a widely available and low-cost material. In dry-cast operations, polymer/solvent/non-solvent systems are only subject to liquid-liquid demixing in a defined set of compositions, building a so-called mixing gap and leading to porous structures. For compositions outside of the mixing gap, the solutions remain homogeneous leading to homogeneous and non-porous structures. The contour of this gap is defined by a binodal curve, which describes phase equilibria in the considered polymer/solvent/non-solvent system (Metze et al. 2017). The main idea of the presented process relies on formulating a polymer system that allows for the composition of the upper part of the cast film to remain outside of the mixing gap during drying while the lower part of the film is forced to undergo liquid-liquid demixing. The product is an asymmetric bilayered film, with an external skin (outer bark) supported by a porous substrate (inner bark).

\section{Materials and methods}

\subsection{Materials}

Eucalyptus kraft lignin (purity $90.6 \%$, ash content: 0.015 $\mathrm{g} / \mathrm{g}$. mean particle size: $0.2 \mathrm{~mm}$ ) was obtained by acid precipitation with $\mathrm{CO}_{2}$ and washing with mineral acid $(\mathrm{pH}$ 2), from Eucalyptus ssp. fresh kraft black liquor, kindly provided by the Fray Bentos pulp mill, Uruguay, using a 


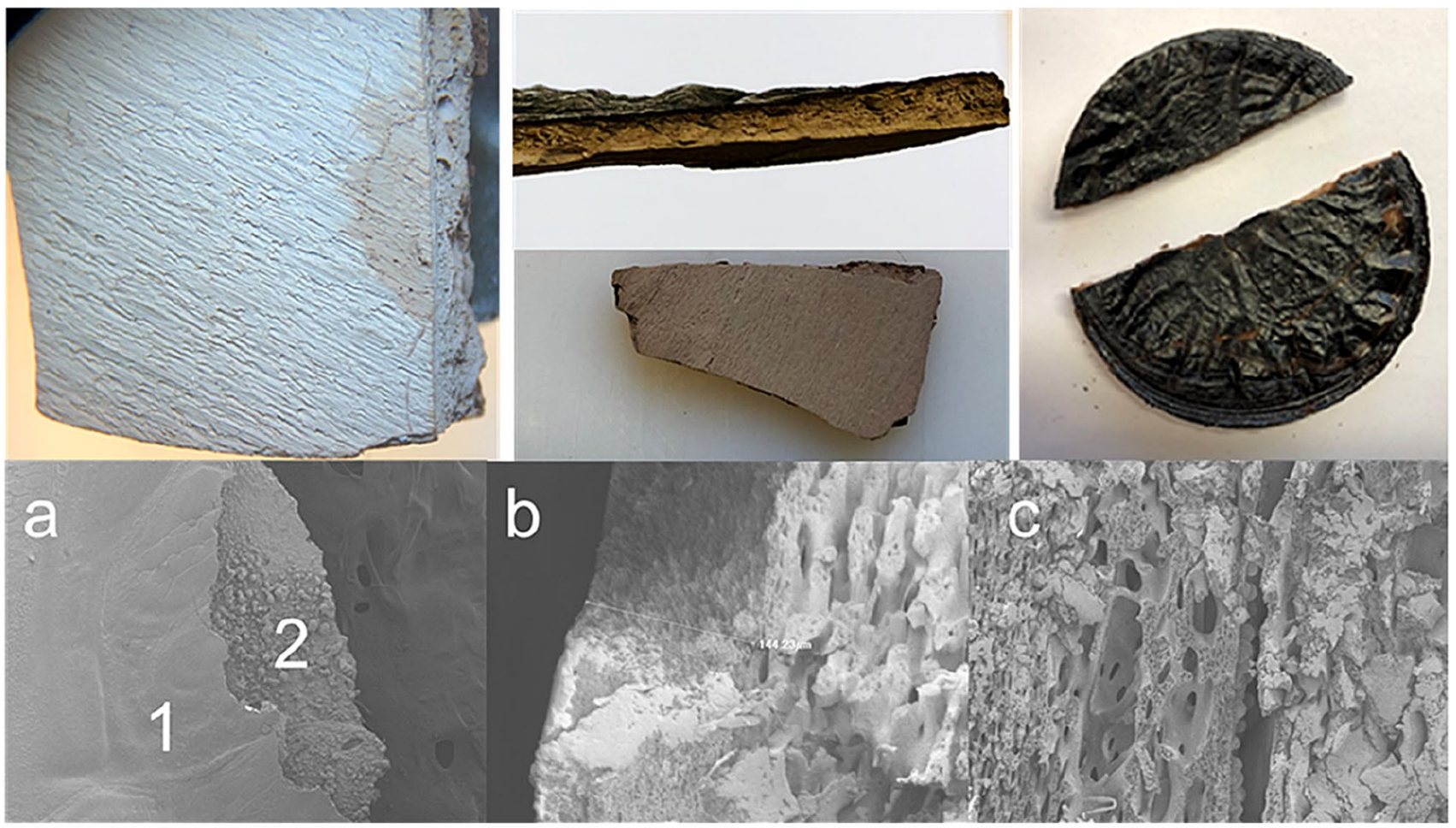

Top Side

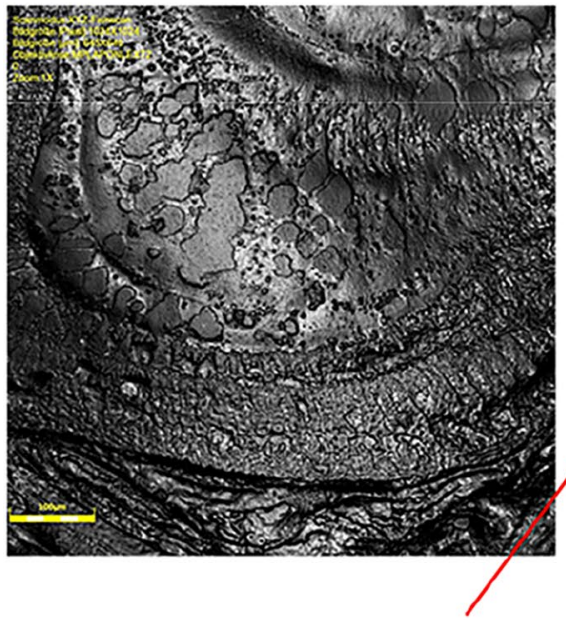

Non-Porous Skin
Cross Section

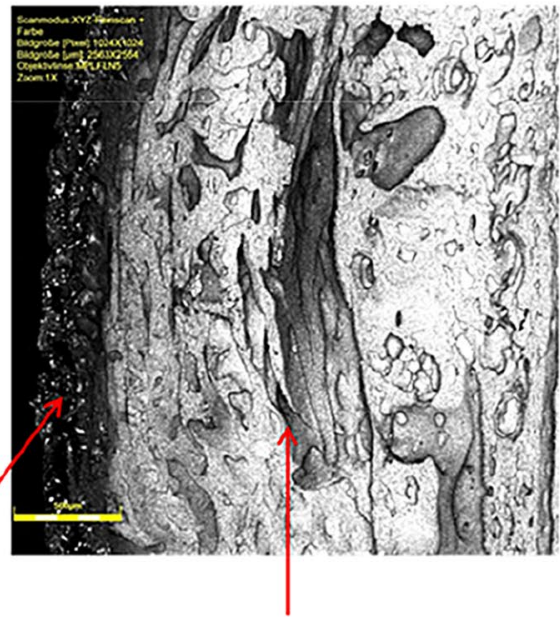

Porous Substrate

Fig. 1 Top - Photographs of the prepared BFs, Middle - SEM micrographs of the BFs a Top side non-porous skin (1) and porous substructure (2); $\mathbf{b}$ cross section of the skin's thickness; $\mathbf{c}$ cross section of the porous substructure, Bottom - LSM micrographs of the BFs

pilot plant designed and built for this purpose (Dieste et al. 2016). CA (L50, Daicel Corporation, $\mathrm{Mn} \sim 107000$ ) with an acetylation degree of 55\% was kindly provided by Sartorius Stedim biotech $\mathrm{GmbH}$. The polymer solution consisted of CA $(0.075 \mathrm{~g} / \mathrm{g}), \mathrm{KL}(0.025 \mathrm{~g} / \mathrm{g})$, acetone $(0.65 \mathrm{~g} / \mathrm{g})$ (purity: 98.00\% purchased from Bernd Kraft $\mathrm{GmbH}$ ) and deionized water $(0.25 \mathrm{~g} / \mathrm{g})$. The required amount of CA was first fully dissolved in acetone in a batch reactor under vigorous stirring for $24 \mathrm{~h}$. Subsequently, the required amount of KL was added under vigorous stirring for further $24 \mathrm{~h}$. Deionized water was slowly added dropwise in order to avoid local liquid-liquid demixing.

The polymer solution was cast with a wet thickness of $10 \mathrm{~mm}$ on beech boards. For this purpose, cylindric molds 

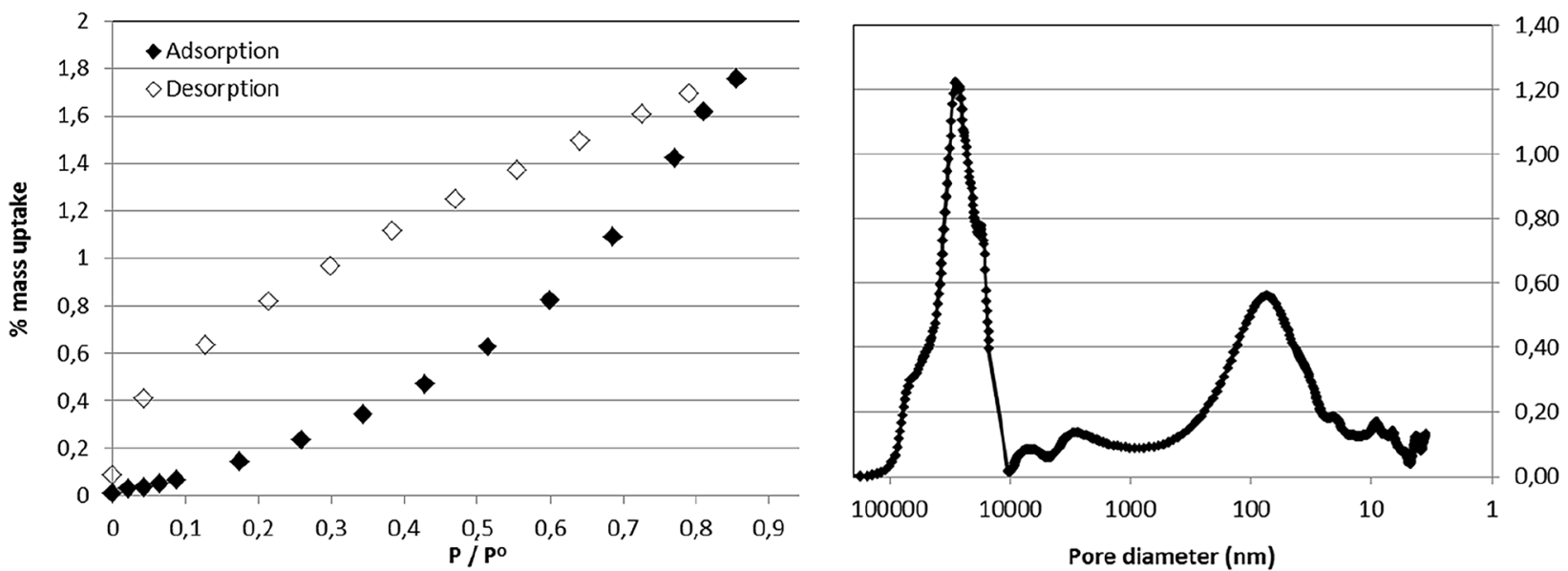

Fig. 2 Left - Water adsorption isotherm of BF measured at $20^{\circ} \mathrm{C}$, Right - Pore size distribution of the reconstructed $\mathrm{BF}$

with a casting diameter of $50 \mathrm{~mm}$ were used. The resulting coatings were left to dry in air at ambient temperature for at least 3 days.

The structures of the prepared coatings were analyzed by laser scanning microscopy (LSM) (OLS 4100, Olympus) and scanning electron microscopy (SEM) (JSM 7401F, Jeol).

The isotherm of the produced material at $20{ }^{\circ} \mathrm{C}$ was determined on an ISOCHEMA IGA system (Hidden); prior to measurements, the sample was outgassed under high vacuum $\left(10^{-6} \mathrm{mT}\right.$ Torr $)$ at $50{ }^{\circ} \mathrm{C}$ for $24 \mathrm{~h}$. BET surface area was measured by means of nitrogen adsorption (Autosorb-1, Quantachrome). Pore distribution was determined by mercury porosimetry (Poremaster, Quantachrome). Bulk density was obtained by helium pycnometry.

\section{Results and discussion}

Photographs of the BF's top side, back side and cross section are shown in Fig. 1 (top). The film had a bark-like appearance. The top side was homogeneous and non-porous (Fig. 1, top); its black color resulted from the presence of KL and a strong water repellence of this surface was observed. The lower part of the film appeared to be highly porous with fingerlike and spherical shaped pores; its structure and the light brown color suggested the assembly of a wood-like matrix. The resulting dry coating thickness was approximately 4-5 mm (Fig. 1, top).

These findings were confirmed by SEM (Fig. 1, middle) and LSM (Fig. 1, bottom) showing a closed, irregular and wavy surface on its top side. The micrographs of the cross section clearly depict the bilayered structure of the film that mimics the superposition of inner and outer bark.

Regarding water adsorption, the isotherm curve is typical for a macroporous material (Fig. 2, left), reaching a low maximum water adsorption capacity of $1.76 \%$ per sample mass at $0.85 \mathrm{P} / \mathrm{P}_{0}$, having a parabolic hysteresis loop, which can be attributed to the existence of hydrogen bonding interactions.

The BF exhibited a much lower hygroscopicity than values reported for natural bark from different coniferous and deciduous wood species, which averaged a maximum adsorption capacity of $26.4 \%$ per sample mass (Ilek et al. 2016). BF's absolute density, bulk density, and total porosity were, $1.25 \pm 0.04 \mathrm{~g} / \mathrm{cm}^{3}, 0.52 \pm 0.016 \mathrm{~g} / \mathrm{cm}^{3}$, and $70.2 \pm 3.21 \%$, respectively. These values are comparable to values measured in natural bark, circa $1.4 \mathrm{~g} / \mathrm{cm}^{3}, 0.5 \mathrm{~g} /$ $\mathrm{cm}^{3}$ and $70.4 \%$, respectively (Ilek et al. 2016). In turn, the BET surface area of the film, $26.79 \mathrm{~m}^{2} / \mathrm{g}\left(\mathrm{r}^{2}=0.99995\right)$, was much higher than that reported for the bark of pine and oak, between 1.00 and $1.40 \mathrm{~m}^{2} / \mathrm{g}$ (Kumar et al. 2014; Zoumis and Calmano 1998). Regarding pore size distribution, the sample had multi-disperse pore sizes with distinctive diameters at 30, 8 and $3 \mu \mathrm{m}$, and $85 \mathrm{~nm}$ (Fig. 2, right).

\section{Conclusion}

This paper is a presentation of a technology that could potentially create novel wood biomimetic coatings based on the dry-cast technique. The presented BF is easily fabricated in a one-step process from natural polymers and exhibits a structure and some physical properties, which are comparable with natural tree bark. Further works will focus on the evaluation of performance and applicability of the film to wood protection.

Acknowledgements Open Access funding provided by Projekt DEAL. 


\section{Compliance with ethical standards}

Conflict of interest The authors declare that they have no conflict of interest.

Open Access This article is licensed under a Creative Commons Attribution 4.0 International License, which permits use, sharing, adaptation, distribution and reproduction in any medium or format, as long as you give appropriate credit to the original author(s) and the source, provide a link to the Creative Commons licence, and indicate if changes were made. The images or other third party material in this article are included in the article's Creative Commons licence, unless indicated otherwise in a credit line to the material. If material is not included in the article's Creative Commons licence and your intended use is not permitted by statutory regulation or exceeds the permitted use, you will need to obtain permission directly from the copyright holder. To view a copy of this licence, visit http://creativecommons.org/licenses/by/4.0/.

\section{References}

Crang R, Lyons-Sobaski S, Wise R (2018) Periderm. In: Crang R, Lyons-Sobaski S, Wise R (eds) Plant anatomy: a concept-based approach to the structure of seed plants. Springer International Publishing, Cham, pp 553-575
Dieste A, Clavijo L, Torres AI, Barbe S, Oyarbide I, Bruno L, Cassella F (2016) Lignin from Eucalyptus spp. Kraft Black Liquor as Biofuel Energy Fuels 30:10494-10498

Ilek A, Kucza J, Morkisz K (2016) Hygroscopicity of the bark of selected forest tree species. iForest 10:220-226

Kumar N, Man H, Woo H (2014) Biosorption of phenolic compounds from aqueous solutions using pine (Pinus densiflora Sieb) bark powder. Bioresources 9:5155-5174

Metze M, Barbe S, Reiche A, Kesting A, Schweins R (2017) A neutrontransparent flow-through cell (NTFT-CELL) for the SANS investigation of microstructure evolution during industrial evaporative casting. J Neutron Res 19(3-4):177-185

Musa S, Richter O, Balsam M, Kneer A, Barbe S (2018) Macroporous films from acetylated lignin and cellulose as precursors for smart coatings based on regenerated wood. Eur J Wood Prod 76:1363-1366

Zoumis T, Calmano W (1998) Development of geochemical barriers for a natural demobilization of heavy metals from mine waters. In: IMWA Symposium Johannesburg. At International Mine Water Association, Johannesburg, 325-328

Publisher's Note Springer Nature remains neutral with regard to jurisdictional claims in published maps and institutional affiliations. 